\title{
ANALYSIS OF BLEACHING PRODUCTS ASSOCIATED WITH DESENSITIZING AGENTS IN EXPERIMENTAL WHITENING GEL - RANDOMIZED CLINICAL TRIAL
}

\author{
ANÁLISE DE PRODUTOS CLAREADORES ASSOCIADOS COM AGENTES \\ DESSENSIBILIZANTES EM GEL CLAREADOR EXPERIMENTAL - ENSAIO \\ CLÍNICO RANDOMIZADO
}

\begin{abstract}
Guilherme Faria MOURA ${ }^{1}$; Daniela Navarro Ribeiro TEIXEIRA ${ }^{1}$; Alexandre Coelho MACHADO ${ }^{1}$; Pedro Henrique Rezende SPINI ${ }^{1}$; Paulo Vinícius SOARES ${ }^{2}$

1. Postgraduate Student and Member of Nucleus Extension, Research and Teaching at NCCL, Dentistry School, Federal University of Uberlandia, Brazil; 2. Associate Professor at Operative Dentistry and Dental Materials Department and Coordinator of Nucleus Extension, Research and Teaching at NCCL, Dentistry School, Federal University of Uberlandia, Brazil. paulovsoares@yahoo.com.br
\end{abstract}

\begin{abstract}
The objective of this clinical study was to determine the effect of adding desensitizing agents in homemade experimental whitening gel Carbamide peroxide 16\%. 60 young patients were selected (between 18-28 years), who used randomly (by lottery) the whitening gel DA (with desensitizing agent) or whitening gel CO (without desensitizing agent) characterized as control of a double-blind study, ie the patient and the evaluator did not know the product that was being used. Teeth 15, 14, 13, 12, 11, 21, 22, 23, 24 and 25 were bleached. The guidelines of how to apply the bleaching agents were performed by an experienced and calibrated team, and the application accompanied by examiners in several phases. To measure the color we used a Visual Range Vita Classical through visual inspection by the evaluators and patient information. A comparative test regarding each individual stimulation caused by mechanical attrition and thermal probe with clinical test was done (air syringe) in order to verify the presence of sensitivity in three phases: before treatment, after 7 and 14 days. Data were collected using Visual Analogue Scale (VAS) adapted to four criteria: no pain, mild pain, moderate pain and severe pain. The correlation of the data $\mathrm{x}$ teeth sensitivity were obtained separately, and tabulated for further comparative analysis. The results showed that there was no difference between the groups in terms of bleaching effect. In the post-operative sensitivity test, the subjects who used the product without desensitizing showed higher levels of sensitivity in different types of teeth, regardless of sex or age. It was concluded that the addition of desensitizing agent in the carbamide peroxide $16 \%$ whitening gel produced less post-bleaching sensitivity index. We emphasize that from the teeth evaluated, the premolars showed higher sensitivity index, followed by the canines and incisors. There was no difference in the bleaching capacity of the products used, demonstrating that the addition of desensitizing did not affect the efficacy of the treatment.
\end{abstract}

KEYWORDS: Bleaching. Sensitivity. Carbamide peroxide. Desensitizing.

\section{INTRODUCTION}

Increased concern has been given to the aesthetic appearance in dentistry in recent years. Patients are increasingly influenced by the media and cultural desires for 'the perfect smile' and consequently they often elect for invasive treatment of disease free teeth (THEOBALD et al., 2006). The most conservative way to modify the color of teeth is the use of a bleaching procedure and it can be made by in-office or at-home bleaching (HAYWOOD, 1989), which is commonly related with the adverse effect of tooth sensitivity, in cases of vital tooth bleaching. It occurs during and after the whitening treatment.

The incidence of hypersensitivity experienced with in-office bleaching is reportedly $10-90 \%$, and is mostly mild or moderate; however, it is sometimes so severe that the treatment is discontinued (KUGEL et al., 2006). Sensitivity is caused by the passage of hydrogen peroxide, which is only slightly larger than water molecules, through enamel and dentin to the pulp where it directly activates nerves that cause pain (BROWNING et al., 2008).

Post-treatment sensitivity is usually related to small microscopic enamel defects and subsurface pores, which allow the whitening agent to penetrate into the dental tubules and ultimately the pulp, causing reversible pulpitis and consequent teeth thermal sensitivity, but not causing permanent damage to the pulp. These responses are correlated with the peroxide concentration, time, frequency of gel application and pulp temperature rise after light activation (BERGA-CABALLERO et al., 2006). Schulte et al. (1994), found that sensitivity was severe enough to cause $14 \%$ of patients to discontinue bleaching treatments. However, dentin exposure may be a factor in tooth sensitivity as it is often misdiagnosed as not being present. 
Dental post-bleaching sensitivity and $\mathrm{DH}$ generally are characterized as acute and of short duration in response to chemical, thermal, tactile or osmotic stimuli within the oral cavity (ORCHARDSON et al., 1994). It is known that the application of whitening gel on exposed dentin is a limiting factor of tooth whitening. However, degraded enamel, no visible cracks and fissures can clinically favor the highest penetration of the bleaching product in the underlying dentin to the enamel.

For the self-applied bleaching (at-home bleaching) it is used hydrogen peroxide at low concentrations or peroxide compounds, usually carbamide peroxide. This modality is performed with individualized silicone tray, made after molding the patient. The technique is guided and supervised by the dental professional, where the whitening product is kept in contact with the tooth surface for periods varying from 15 minutes to 8 hours repeated more than a day (RIEHL et al., 2008).

It is known that certain factors should be considered: the concentration and composition of the bleaching agent, the diffusion capacity due to its low molecular weight or permeability of dental structures, the exposure time and temperature used to catalyze the chemical reaction of the material. The wrong association of technique or neglect of any step can generate hypersensitivity and discomfort to the patient, compromising the aesthetic treatment.

Considering the desensitizing action of the nerves (BARTOLD, 2006; PORTO, ANDRADE e MONTES, 2009), the agent based on nitrate and potassium has a history of success in the treatment of dentin hypensensitivity (HODOSH, 1974; TARBET et al., 1980). Despite this proved efficacy, its mechanism of action is not already completely clarified. The most probable explanation is that the postassium ions active components and the potassium nitrate reduces the activity of the sensorial nerve present in dentin. It occurs due to the activity of ions $\mathrm{K}^{+}$(MARLOWITZ e KIM, 1990).

Faced with this reality, the authors of this study propose to clinically analyze the effect of the addition of a type of desensitizing agent in the chemical composition of an experimental whitening gel in a group of volunteer patients. The null hypothesis is that the addiction of desensitizing agent will not interfere on post-bleaching sensitivity neither in bleaching treatment efficacy.

\section{MATERIALS AND METHODS}

\section{Selection of patients}

First, the study protocol was submitted to the Ethics Committee (protocol \# 3660961.3.0000.5152). Upon approval, the individuals were selected at the Dental Hospital, in Federal University of Uberlândia (Uberlândia-MG, Brazil).

Patients free of caries, with no clinical exposures of dentin, visible cracks or fractures and extensive or poor restorations, adequate and satisfactory oral hygiene, and absence of periodontal disease or parafunctional habits were eligible for this study. They also presented no pain after inspection tests with thermal and mechanical test (triple syringe - air jet $1 \mathrm{~cm}$ away by two seconds). The general state of the patient's health was assessed by clinical history, and those with systemic and/or serious psychological diseases, constant use of analgesic and/or anti-inflammatory medicines or allergic response to dental products were excluded.

Patient selection was based on clinical examination and detailed history. The clinical diagnosis was performed using a uniform light source, provided by a conventional light system, a mirror and a dental explorer probe. The selection of the study subjects and the history, the DMFS (decayed, missing and filled surfaces), VPI (visible plaque index), GBI (gingival bleeding index) and the initial record of the tooth color were performed by the responsible team. Periapical radiographs of the arch were made by the technician of Radiology, at Dental Hospital. The sample consisted of 60 subjects, male (28) and female (32), aged 18-28 years, which have never performed any kind of bleaching. The participants were informed about the purpose of research and signed an appropriate consent form.

\section{Application of whitening gel}

All 60 study subjects received the peroxide carbamide $16 \%$ whitening gel with potassium nitrate desensitizing agent (DA), not known by staff, and the whitening gel without the desensitizing, considered as control (CO). As the study is featured as double-blind, the products were not identified in the packaging, ie, subjects and assessors were unaware of the identity of the products used. They were randomly distributed, and only the researcher in charge knew the distribution code by lottery. First, only the upper arch (teeth 15-25) was bleached and considered as result for this study. Upon standardized research completed, the bleaching of lower arch was offered to the subjects. 


\section{Bleaching}

Individual silicone trays, obtained by plaster models applied in vacuum laminator were made. The models were obtained by molding using silicone addition material. The distribution of products for the subjects was randomly performed. The subjects received printed clinical guidelines and were followed throughout the bleaching stage by the investigators.

Each subject received one sample of the product. On the beginning of the treatment, the two compartments of the product had to be blended, so it starts to work appropriately. When it was completely mixed, it was ready for use. The patients were advised to deposit a drop in the bottom of each tooth impression in the tray.

Each subject performed bleaching for four hours a day through 14 days, uninterrupted. To avoid gingival allergic reactions, cervical clipping was done in order to prevent leakage of the product. It was realized three data collect, on three different moments, as described below.

\section{Collection of hypersensitivity data}

The values were always collected before and after the treatments. Each tooth received two stimuli: attrition through explorer probing (mechanical stimulation) and air blast (thermalosmotic stimulus) in all teeth (15-25). For the subject discern the pain from a tooth and another, initially, the stimulus was applied on a tooth that not received the direct contact with the whitening gel, for both tests. The stimulus was applied by the probe under slight hand pressure on mesiodistal direction in the cervical area and middle third of each tooth. Jets of air were applied with the triple syringe for two seconds at a distance of $1 \mathrm{~cm}$ from the surface and the adjacent teeth was protected with cotton. If the sensitivity pain was identify, the examiner waited it stop and only then passed to the evaluation of the next tooth, decreasing the risk of misidentification of tooth sensitivity.

In addition, there was a report by the patient in order to quantify the pain in their daily lives when faced with situations that led to dentin hypersensitivity.

After that, the degree of hypersensitivity was determined according to the Visual Analog Scale (VAS). This is a scale that goes from 0 to 10 , which indicates the pain as absent $(0)$, mild $(1-3)$, moderate $(4-7)$ or intense $(8-10)$, as shown in Table 1.

Table 1. Measurement of pain by the Visual Analog Scale.

\begin{tabular}{|l|c|c|}
\hline \multirow{4}{*}{ PAIN LEVEL (VAS) } & absent & $\mathbf{0}$ \\
\cline { 2 - 3 } & mild & $\mathbf{1}-\mathbf{3}$ \\
\cline { 2 - 3 } & moderate & $\mathbf{4}-\mathbf{7}$ \\
\cline { 2 - 3 } & intense & $\mathbf{8}-\mathbf{1 0}$ \\
\hline
\end{tabular}

\section{Collection of color alteration data}

All patients were examined by two examiners at different times, using classical color scale (Vita Classic) in environments with the same illumination pattern. For teaching purposes, digital pictures were taken. The measurements of color were carried before treatment $(\mathrm{C} 1)$, after seven days (C2) and fourteen days of the bleaching (C3). Considering the presence of initial sensitivity as exclusion criteria, the measurement of sensibility was carried after seven days (DH1) and fourteen days (DH2) after bleaching.

\section{RESULTS}

All subjects did not experience pain under the two types of stimuli in DH1 of the trial. There was no difference between DA and CO in terms of bleaching effectiveness. All subjects were satisfied with the result of the bleaching agent and final color after 14 days.

For the post-bleaching sensitivity test, it can be seen that the behavior of the products was different. The subjects who used the bleaching agent without addition of desensitizing (CO) showed higher sensitivity levels, in different types of tooth, regardless of gender or age. These results can be observed in detail in the following tables and figures. 
Table 2. Data distribution of tooth x hypersensitivity level for DA on DH1 ( $\mathrm{n}=30)$

\begin{tabular}{lrrrrrrrrrr}
\hline & $\mathbf{1 5}$ & $\mathbf{1 4}$ & $\mathbf{1 3}$ & $\mathbf{1 2}$ & $\mathbf{1 1}$ & $\mathbf{2 1}$ & $\mathbf{2 2}$ & $\mathbf{2 3}$ & $\mathbf{2 4}$ & $\mathbf{2 5}$ \\
\hline absent & $97.7 \%$ & $93.3 \%$ & $100.0 \%$ & $97.7 \%$ & $100.0 \%$ & $100.0 \%$ & $100.0 \%$ & $97.7 \%$ & $83.3 \%$ & $86.7 \%$ \\
mild & $3.3 \%$ & $6.7 \%$ & $0.0 \%$ & $3.3 \%$ & $0.0 \%$ & $0.0 \%$ & $0.0 \%$ & $3.3 \%$ & $16.7 \%$ & $13.3 \%$ \\
moderate & $0.0 \%$ & $0.0 \%$ & $0.0 \%$ & $0.0 \%$ & $0.0 \%$ & $0.0 \%$ & $0.0 \%$ & $0.0 \%$ & $0.0 \%$ & $0.0 \%$ \\
intense & $0.0 \%$ & $0.0 \%$ & $0.0 \%$ & $0.0 \%$ & $0.0 \%$ & $0.0 \%$ & $0.0 \%$ & $0.0 \%$ & $0.0 \%$ & $0.0 \%$ \\
\hline
\end{tabular}

Table 3. Data distribution of tooth x hypersensitivity level for DA on DH2 ( $\mathrm{D}=30)$

\begin{tabular}{lrrrrrrrrrr}
\hline & $\mathbf{1 5}$ & \multicolumn{1}{c}{$\mathbf{1 4}$} & $\mathbf{1 3}$ & $\mathbf{1 2}$ & $\mathbf{1 1}$ & $\mathbf{2 1}$ & $\mathbf{2 2}$ & $\mathbf{2 3}$ & $\mathbf{2 4}$ & $\mathbf{2 5}$ \\
\hline absent & $90.0 \%$ & $86.7 \%$ & $86.7 \%$ & $100.0 \%$ & $97.7 \%$ & $97.7 \%$ & $100.0 \%$ & $100.0 \%$ & $83.3 \%$ & $86.7 \%$ \\
mild & $10.0 \%$ & $13.3 \%$ & $13.3 \%$ & $0.0 \%$ & $3.3 \%$ & $3.3 \%$ & $0.0 \%$ & $0.0 \%$ & $16.7 \%$ & $13.3 \%$ \\
moderate & $0.0 \%$ & $0.0 \%$ & $0.0 \%$ & $0.0 \%$ & $0.0 \%$ & $0.0 \%$ & $0.0 \%$ & $0.0 \%$ & $0.0 \%$ & $0.0 \%$ \\
intense & $0.0 \%$ & $0.0 \%$ & $0.0 \%$ & $0.0 \%$ & $0.0 \%$ & $0.0 \%$ & $0.0 \%$ & $0.0 \%$ & $0.0 \%$ & $0.0 \%$ \\
\hline
\end{tabular}

Table 4. Data distribution of tooth $\mathrm{x}$ hypersensitivity level for $\mathrm{CO}$ on DH1 $(\mathrm{n}=30)$

\begin{tabular}{lrrrrrrrrrr}
\hline & $\mathbf{1 5}$ & $\mathbf{1 4}$ & $\mathbf{1 3}$ & $\mathbf{1 2}$ & $\mathbf{1 1}$ & $\mathbf{2 1}$ & $\mathbf{2 2}$ & $\mathbf{2 3}$ & $\mathbf{2 4}$ & $\mathbf{2 5}$ \\
\hline absent & $76.7 \%$ & $73.3 \%$ & $73.3 \%$ & $83.3 \%$ & $83.3 \%$ & $80.0 \%$ & $76.7 \%$ & $73.3 \%$ & $66.7 \%$ & $70.0 \%$ \\
mild & $6.7 \%$ & $20.0 \%$ & $6.7 \%$ & $16.7 \%$ & $16.7 \%$ & $10.0 \%$ & $16.7 \%$ & $20.0 \%$ & $23.3 \%$ & $26.7 \%$ \\
moderate & $16.6 \%$ & $0.0 \%$ & $20.0 \%$ & $0.0 \%$ & $0.0 \%$ & $0.0 \%$ & $3.3 \%$ & $6.7 \%$ & $0.0 \%$ & $3.3 \%$ \\
intense & $0.0 \%$ & $6.7 \%$ & $0.0 \%$ & $0.0 \%$ & $0.0 \%$ & $10.0 \%$ & $3.3 \%$ & $0.0 \%$ & $10.0 \%$ & $0.0 \%$ \\
\hline
\end{tabular}

Table 5. Data distribution of tooth $x$ hypersensitivity level for $\mathrm{CO}$ on $\mathrm{DH} 2(\mathrm{n}=30)$

\begin{tabular}{lrrrrrrrrrr}
\hline & $\mathbf{1 5}$ & $\mathbf{1 4}$ & $\mathbf{1 3}$ & $\mathbf{1 2}$ & $\mathbf{1 1}$ & $\mathbf{2 1}$ & $\mathbf{2 2}$ & $\mathbf{2 3}$ & $\mathbf{2 4}$ & $\mathbf{2 5}$ \\
\hline absent & $53.3 \%$ & $40.0 \%$ & $63.4 \%$ & $73.3 \%$ & $66.7 \%$ & $50.0 \%$ & $66.7 \%$ & $56.7 \%$ & $46.7 \%$ & $40.0 \%$ \\
mild & $13.3 \%$ & $16.7 \%$ & $13.3 \%$ & $0.0 \%$ & $20.0 \%$ & $16.7 \%$ & $0.0 \%$ & $3.3 \%$ & $36.7 \%$ & $23.3 \%$ \\
moderate & $26.7 \%$ & $33.3 \%$ & $23.3 \%$ & $26.7 \%$ & $13.3 \%$ & $30.0 \%$ & $23.3 \%$ & $23.3 \%$ & $0.0 \%$ & $26.7 \%$ \\
intense & $6.7 \%$ & $10.0 \%$ & $0.0 \%$ & $0.0 \%$ & $0.0 \%$ & $3.3 \%$ & $10.0 \%$ & $16.7 \%$ & $16.6 \%$ & $10.0 \%$ \\
\hline
\end{tabular}

Figure1. Data distribution of tooth $x$ hypersensitivity level for DA on DH1 $(n=30)$

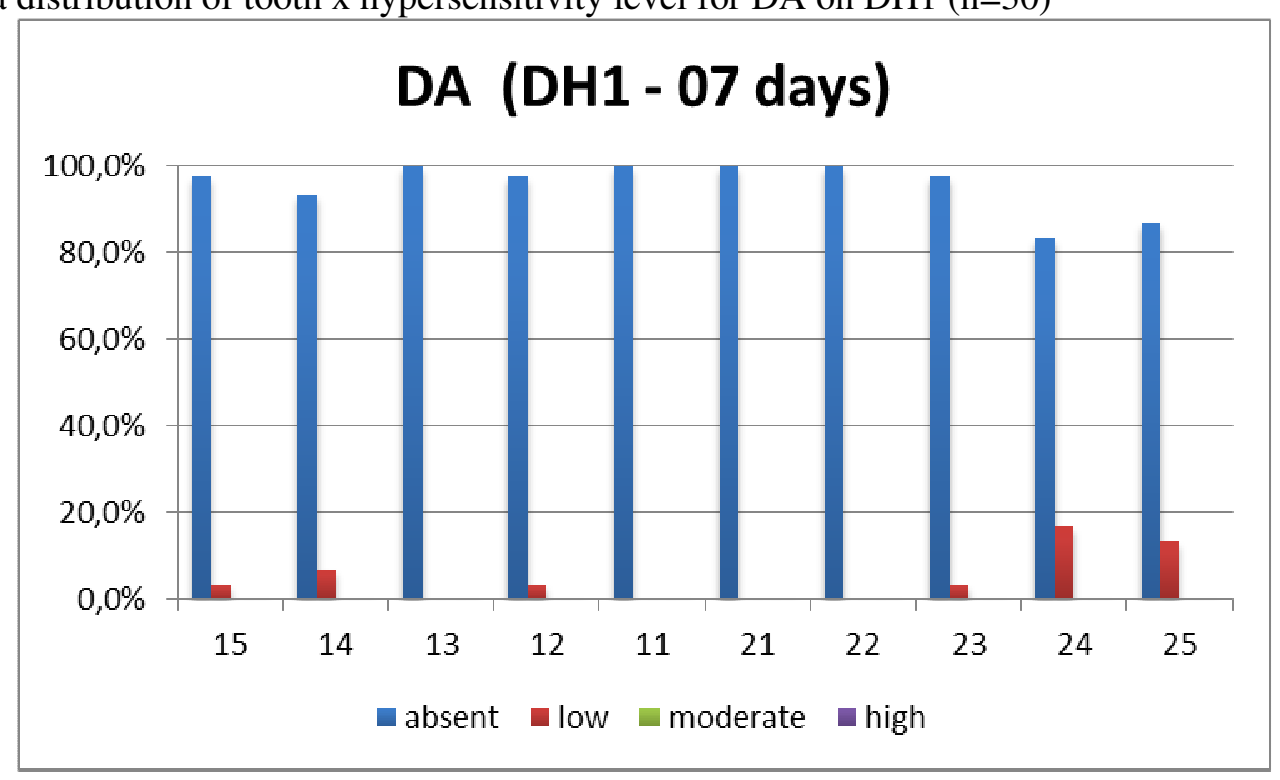


Figure 2. Data distribution of tooth $x$ hypersensitivity level for DA on DH2 (n=30)

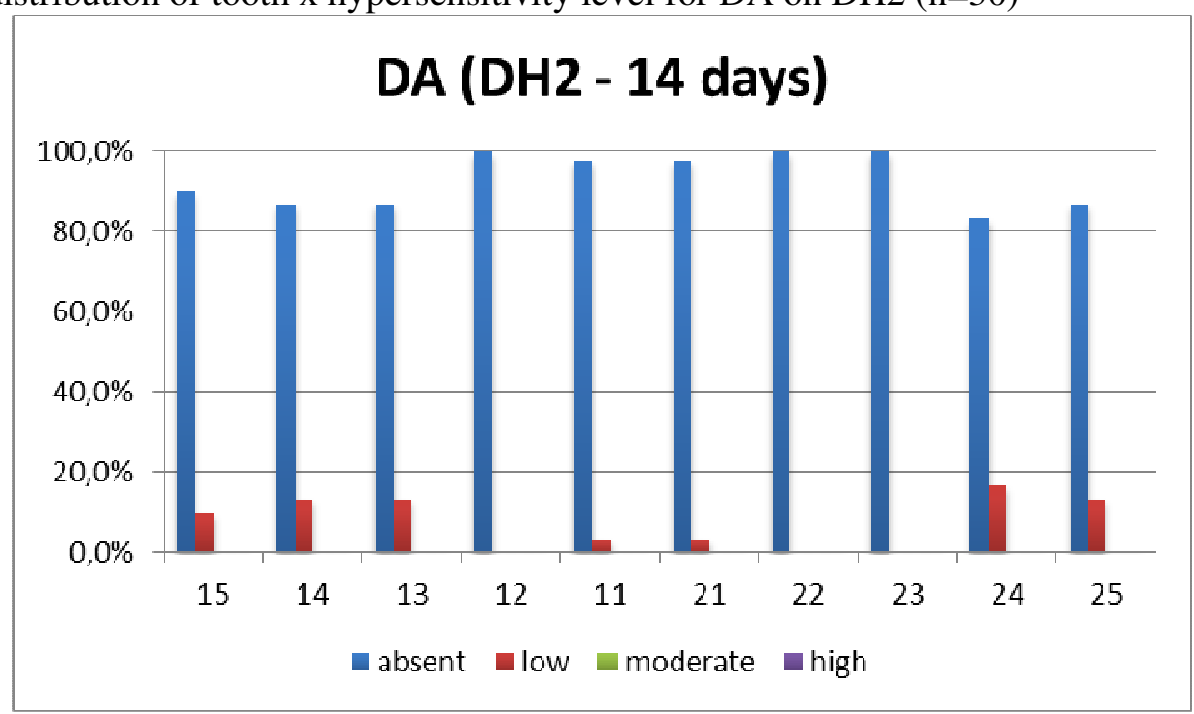

Figure 3. Data distribution of tooth x hypersensitivity level for CO on DH1 (n=30)

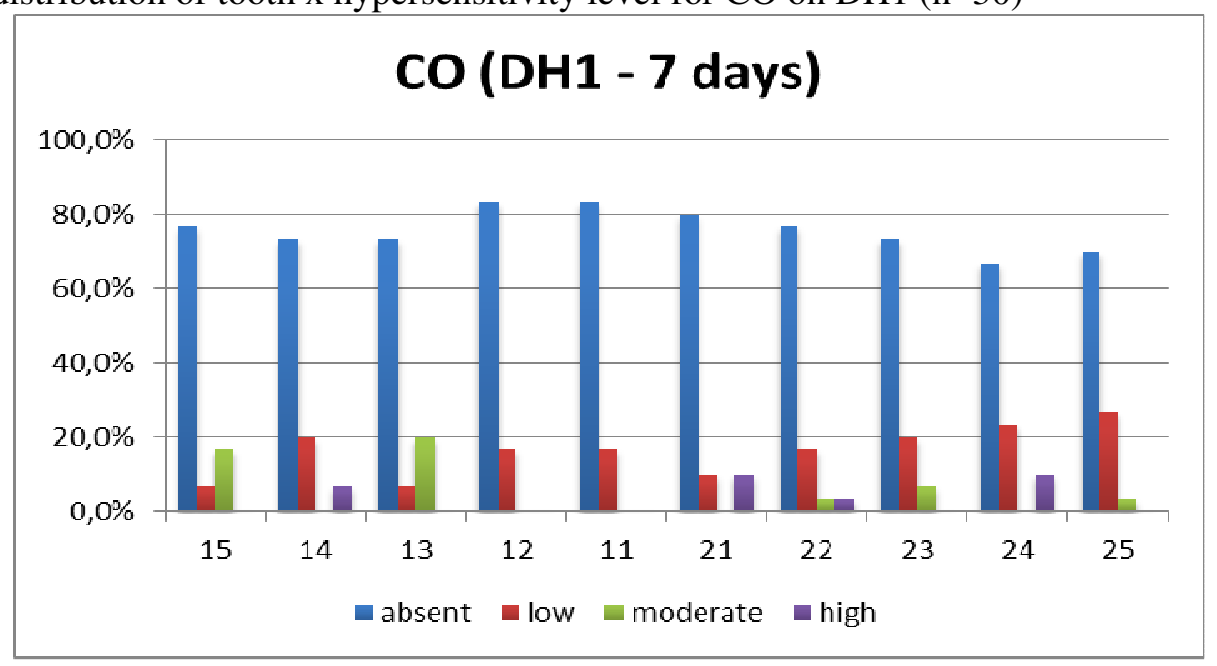

Figure 4. Data distribution of tooth $x$ hypersensitivity level for CO on DH2 (n=30)

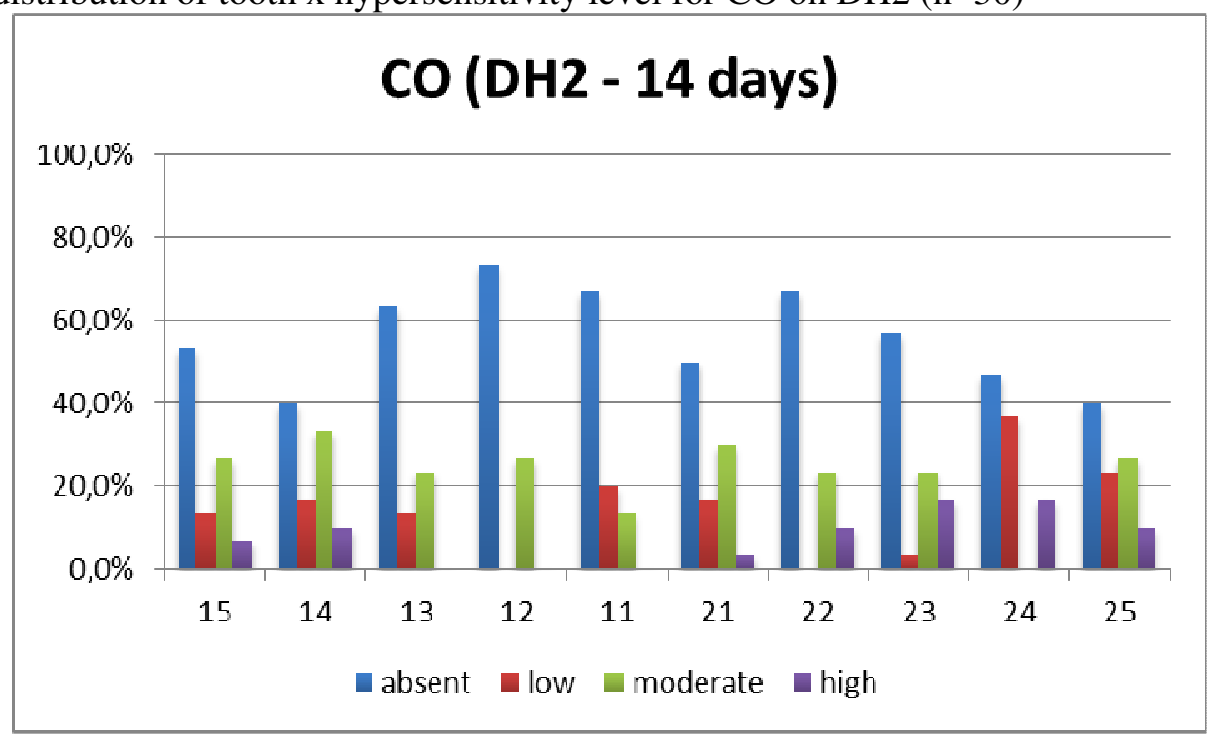


In DH1, four subjects using CO reported severe pain. They were instructed by the team to discontinue bleaching, but opted to follow the next phase (DH2) of the research for free, spontaneous and individual decision. They reported no pain after tray removal with $\mathrm{CO}$.

The phase DH2 showed a higher discrepancy among the products. In the comparative association data, it was found high rates of mild, moderate and intense sensitivity for the use of $\mathrm{CO}$ in different types of teeth, especially premolars. The moderate and intense sensitivity rates increased from Phase DH1 to DH2.

The group of subjects who used DA showed mild sensitivity level, which increased from phase DH1 to DH2, especially in premolars. On the other hand, during the final clinical exams, they reported that this sensitivity only occurred when stimulated by the evaluators, not occurring in their daily routine.

\section{DISCUSSION}

The results of this Randomized clinical trial study demonstrated that dentist-supervised at-home bleaching with both tested products (whitening gel with or without desensitizers) for 14 days led to increased tooth sensitivity; however, the 16\% carbamide peroxide gel with the desensitizing agents induced lower hypersensitivity than the product without it. In contrast, there was no visual difference between the two groups in terms of bleaching efficacy. Thus, the null hypothesis was rejected.

The patient's sensitivity may have been caused by the passage of hydrogen peroxide through enamel and dentin to the pulp, causing reaction of pain (BROWNING et al., 2008). It can be also related to small microscopic enamel defects and subsurface pores, which cannot be seen clinically. These responses go along with the peroxide concentration, time and frequency of gel application (BERGA-CABALLERO et al., 2006), which were controlled according to the manufacture's instructions at the present study.

Considered as a sensorial and emotional unpleasant experience, pain has a strong subjective character (MERSKEY H, BODGUK N; 1986). Because of this, the visual analogue scale (VAS) is considered a simple and effective method to evaluate the variations of the pain intensity (CHAPMAN et al., 1985). The visual analogue scale of pain is extremely important for the treatment of bleaching, as it is possible to track quantitatively its progress.
Increased sensitivity after bleaching confirms previous reports of tooth sensitivity as a recurring side effect of at-home bleaching (HAYWOOD et al., 1994; LEONARD et al., 1997; DELIPERI et al., 2004). Some authors suggest the use of desensitizers during the bleaching, because even if the desensitizing treatment does not reduce the incidence of tooth sensitivity, it is able to reduce its intensity (HAYWOOD et al., 2001; Armênio et al., 2008). Recently, the blending of desensitizing agents within bleaching products has been proposed by manufacturers to reduce tooth sensitivity after bleaching procedures.

A clinical trial (NAVARRA et al., 2014) was made with twenty subjects using a 10\% carbamide peroxide gel with or without fluoride and potassium nitrate for 2 weeks. Sensitivity, spectrophotometric evaluation of color and morphological analyses of replicas with scanning electron microscope (SEM) were performed before and after treatment. The results showed that the use of $10 \%$ carbamide peroxide gel with fluoride and potassium nitrate reduced the incidence of sensitivity during the bleaching treatment compared to a bleaching agent that did not contain desensitizing agents. The bleaching effectiveness of the tested products was similar.

Another clinical trial (MEHTA et al., 2013) compared tooth sensitivity during and after bleaching with hydrogen peroxide gel following application of GLUMA Desensitizer PowerGel or placebo. The results, once again, showed that prebleaching application of the desensitizing agent significantly reduced tooth sensitivity during and after bleaching when compared with treatment with placebo.

It has been supposed that products such as fluoride and amorphous calcium phosphate can occlude the dentinal tubules due to the precipitation of calcium fluoride crystals or hydroxyapatite crystals able to settle on the tooth surface (ARMÊNIO et al., 2008; BROWNING et al., 2008; GINIGER et al., 2005; GROBLER et al., 2011). This way, it decreasing the excitability of the pulpal nerve fibers, inducing an anesthetic effect (HAYWOOD et al., 2001), or reducing the dentinal fluid by blocking the tubule orifices, this way relieving the patient's pain. All these results confirm, along with this study, that tooth sensitivity can be effectively decreased by addition of desensitizing agents, such as fluoride and potassium nitrate, to at-home bleaching products.

To validate the results of this study, more independent clinical trials must be realized with other specific population rather than patients with 
dentin hypersensitivity, such as: high performance athletes, patients with gastroesophageal reflux disease, patients with acid eating habits, patients with parafunctional habits, among others.

\section{CONCLUSION}

Within the limitations of this study, it can be concluded that the addition of potassium nitrate desensitizing agent in the carbamide peroxide $16 \%$ whitening gel produced less post-bleaching sensitivity index, major in premolars. There was no difference in the bleaching capacity of the products used, demonstrating that the addition of desensitizing did not compromise the bleaching treatment.

\section{ACKNOWLEDGMENTS}

This study was supported by Brazilian Public Agencies CAPES, FAPEMIG (grant \#APQ02504-12) and CNPq (grant \#454453/2014$0)$. The authors would like to thank the Integrated Dental Research Laboratory of the Federal University of Uberlândia (CPBio) and Public Ambulatory to treatment patients with NCCL and CDH, NCCL Research Group (Dentistry School and Dental Hospital- Federal University of Uberlândia).

RESUMO: O objetivo deste estudo clínico foi determinar o efeito da adição de agentes dessensibilizantes em gel clareador experimental caseiro Peróxido de Carbamida 16\%. Foram selecionados 60 pacientes jovens (entre 18 a 28 anos), que utilizaram aleatoriamente (através de sorteio) o gel clareador DA (com dessensibilizante) gel clareador CO (sem dessensibilizante), caracterizado como grupo controle de um estudo duplo-cego, ou seja o paciente e o avaliador não conheciam o produto que estava sendo utilizado. Foram clareados os dentes 15, 14, 13, 12, 11, 21, 22, 23, 24 e 25. As orientações de como aplicar os agentes clareadores foram realizadas por uma equipe experiente e calibrada, e a aplicação acompanhada por examinadores em diversas fases. Para mensuração da cor foi utilizada uma Escala Visual Vita Clássica através de inspeção visual pelos avaliadores e informações dos pacientes. Foi feito um teste comparativo considerando cada estímulo individualmente provocado por atrito mecânico com sonda clínica e teste térmico (seringa de ar), a fim de verificar a presença de sensibilidade em três fases: antes do tratamento, após 7 e 14 dias. Os dados foram coletados utilizando Escala Visual Analógica (EVA) adaptada a quatro critérios: ausência de dor, dor leve, dor moderada e dor intensa. A correlação dos dados dentes x sensibilidade foram obtidos separadamente, e tabulados para posterior análise comparativa. Os resultados demonstraram que não existiu diferença entre os grupos em termos de efeito clareador. Já no teste de sensibilidade pós-operatória, os sujeitos que utilizaram o produto sem o dessensibilizante mostraram maiores níveis de sensibildade, em diferentes tipos de dentes, independente de gênero ou idade. Pode-se concluir que a adição do agente dessensibilizante no gel clareador peróxido de carbamida 16\% gerou menor índice de sensibilidade pósclareamento. Destacamos que dentre os dentes avaliados, os pré-molares apresentaram maior índice de sensibilidade, seguido pelos caninos e incisivos. Não houve diferença na capacidade de clareamento dos produtos empregados, demonstrando que a adição do dessensibilizante não comprometeu a eficácia do tratamento.

PALAVRAS-CHAVE: Clareamento. Sensibilidade. Peróxido de carbamida. Dessensibilizante.

\section{REFERENCES}

AL-SAUD, L. M.; AL-NAHEDH, H. N. Occluding effect of Nd:YAG laser and different dentin desensitizing agents on human dentinal tubules in vitro: a scanning electron microscopy investigation. Oper Dent, Indiana, v. 37, n. 4, p. 340-55, jul-aug. 2012.

ARMÊNIO, R. V.; FITARELLI, F.; ARMÊNIO, M. F.; DEMARCO, F. F.; REIS, A.; LOGUERCIO, A. D. The effect of fluoride gel use on bleaching sensitivity: a double-blind randomized controlled clinical trial. $\mathbf{J}$ Am Dent Assoc, USA, v. 139, n. 5, p. 592-97, may, 2008.

ASSIS, J. S.; RODRIGUES, L. K.; FONTELES, C. S.; COLARES, R. C.; SOUZA, A. M.; SANTIAGO S. L. Dentin hypersensitivity after treatment with desensitizing agents: a randomized, double-blind, split-mouth clinical trial. Braz Dent J, Ribeirão Preto, v. 22, n. 2, p. 157-61, 2011.

BARTOLD, P. M. Dentinal hypersensitivity: a review. Aust Dent J, Australia, v. 51, n. 3, p. 212-218; quiz 276, 2006. 
BERGA-CABALLERO, A.; FORNER-NAVARRO, L.; AMENGUAL-LORENZO, J. At-home vital bleaching: A comparison of hydrogen peroxide and carbamide peroxide treatments. Med Oral Patol Oral Cir Bucal, Valencia, v. 11, p. 94-9, 2006.

BROWNING, W. D.; CHAN D. C.; MYERS, M. L; BRACKETT, W. W.; BRACKETT, M. G.; PASHLEY, D. H. Comparison of traditional and low sensitivity whiteners. Oper Dent, Indiana, v. 33, n. 4, p. 379-85, jul-aug. 2008.

CHAPMAN, C. R.; CASEY, K. L.; DUBNER, R.; FOLEY, K. M.; GRACELY, R. H.; READING, A. E. Pain measurement: an overview. Pain Supp, Seattle, v. 22, n. 1, p. 1-31, 1985.

DELIPERI, S.; BARDWELL, D. N.; PAPATHANASIOU, A. Clinical evaluation of a combined in-office and take-home bleaching system. J Am Dent Assoc, USA, v. 135, n. 5, p. 628-34, may, 2004.

GINIGER, M.; SPAID, M.; MACDONALD, J.; FELIX, H. A 180-day clinical investigation of the tooth whitening efficacy of a bleaching gel with added amorphous calcium phosphate. J Clin Dent, Yardley, v. 16, n. 1, p. 11-16, 2005.

GROBLER, S. R.; MAJEED, A; MOOLA, M. H.; ROSSOUW, R. J.; VAN, W. Y. K.; KOTZE, T. In vivo spectrophotometric assessment of the tooth whitening effectiveness of nite white $10 \%$ with amorphous calcium phosphate, potassium nitrate and fluoride, over a 6-month period. Open Dent J, Dallas, v. 2, n. 5, p. 18-23, mar. 2011.

HAYWOOD, V. B.; HEYMANN, H. O. Nightguard vital bleaching. Quintessence Int, Rochester, v. 20, p. 173-6, 1989.

HAYWOOD, V. B.; CAUGHMAN, W. F.; FRAZIER, K. B.; MYERS, M. L. Tray delivery of potassium nitrate-fluoride to reduce bleaching sensitivity. Quintessence Int, Rochester, v. 32, n. 2, p. 105-9, feb. 2001.

HAYWOOD, V. B.; LEONARD, R. H.; NELSON, C. F.; BRUNSON, W. D. Effectiveness, side effects and long term status of nightguard vital bleaching. J Am Dent Assoc, USA, v. 125, n. 9, p. 1219-26, sep. 1994.

HODOSH, M. A superior desensitizer--potassium nitrate. J Am Dent Assoc, Chicago, v. 88, n. 4, p. 831-832, 1974.

MERSKEY, H.; BODGUK, N. International association for the study of pain. Classification of chronic pain. Descriptions of chronic pain syndromes and definitions of pain terms. Prepared by the International Association for the Study of Pain, Subcommittee on Taxonomy. Pain Suppl, Seattle v. 3, n., p. S1-226, 1986.

KUGEL G, PAPATHANASIOU A, WILLIAMS AJ, ANDERSON C, FERREIRA S. Clinical evaluation of chemical and light-acti- vated tooth whitening systems. Compend Contin Educ Dent, Philadelphia, v. 27, p. 54-62, 2006.

LEONARD, R. H.; HAYWOOD, V. B.; PHILLIPS, C. Risk factors for developing tooth sensitivity and gingival irritation associated with nightguard vital bleaching. Quintessence Int, Rochester, v. 28 n. 8, p. $527-$ 34, aug. 1997.

MEHTA, D.; VENKATA, S.; NAGANATH, M.; LINGAREDDY, U.; ISHIHATA, H.; FINGER, W. J. Clinical trial of tooth desensitization prior to in-office bleaching. Eur J Oral Sci, Sweden, v. 121, n. 5, p. 47782, oct. 2013. 
MARSON, F. C.; SENSI, L. G.; VIEIRA, L. C. C.; ARAÚJO, E. Clinical evaluation of in- office dental bleaching treatments with and without the use of light-activation sources. Oper Dent, Indiana, v. 33, n. 1, p. 15-22, jan-feb. 2008.

NAVARRA, C. O.; REDA, B.; DIOLOSA, M.; CASULA, I.; DI LENARDA, R.; BRESCHI, L.; CADENARO, M. The effects of two $10 \%$ carbamide peroxide nightguard bleaching agents, with and without desensitizer, on enamel and sensitivity: an in vivo study. Int J Dent Hygiene, Bochum, v. 12, n. 2, p. 115-20, may. 2014.

ORCHARDSON, R.; GANGAROSA, L. P.; HOLLAND, G. R.; PASHLEY, D. H.; TROWBRIDGE, H. O.; ASHLEY, F. P.; et al. Dentine hypersensitivity into the 21st century. Arch Oral Biol, London, v. 39, suppl. 113S-119S, 1994.

PALAZON, M. T.; SCARAMUCCI, T.; ARANHA, A. C.; PRATES, R. A.; LACHOWSKI, K. M.; HANASHIRO, F. S.; YOUSSEF, M. N. Immediate and short-term effects of in-office desensitizing treatments for dentinal tubule occlusion. Photomed Laser Surg, Rochester, v. 31, n. 6, p. 274-82, jun. 2013.

PORTO, I. C.; ANDRADE, A. K.; MONTES, M. A. Diagnosis and treatment of dentinal hypersensitivity. J Oral Sci, Japan, v. 51, n. 3, p. 323-332, 2009.

PRADEEP, A. R.; AGARWAL, E.; NAIK, S. B.; BAJAJ, P.; KALRA, N. Comparison of efficacy of three commercially available dentifrices [corrected] on dentinal hypersensitivity: a randomized clinical trial. Aust Dent J, Australia, v. 57, n. 4, p. 429-34, dec.

RIEHL, H.; FRANCCI, C.; COSTA, C. A. S.; RIBEIRO, A. P. D.; CONCEIÇÃO, E. N. Clareamento de dentes vitais e não vitais: uma visão crítica. In: Fonseca, A. S. (Org.). Odontologia Estética: a arte da perfeição. São Paulo: Artes Médicas, 2008. p. 499-565.

RITTER, A. V. (2006). In-office tooth bleaching. J Esthet Restor Dent, North Carolina, v. 18, n. 3, p. 168-9, 2006. http://dx.doi.org/10.1111/j.1708-8240.2006.00010.x

SCHMIDT, C. J.; TATUM, S. A. Cosmetic dentistry. Curr Opin Otolaryngol Head Neck Surg, California, v. 14 , n. 4 , p. 254-9, aug. 2006.

SHARMA, N.; ROY, S.; KAKAR, A.; GREENSPAN, D. C.; SCOTT, R. A clinical study comparing oral formulations containing $7.5 \%$ calcium sodium phosphosilicate (NovaMin), $5 \%$ potassium nitrate, and $0.4 \%$ stannous fluoride for the management of dentin hypersensitivity. J Clin Dent, Yardley, v. 21, n. 3, p. 88-92, 2010.

SCHULTE, J. R.; MORRISSETTE, D. B.; GASIOR, E. J.; CZAJEWSKI, M. V. The effects of bleaching application time on the dental pulp. J Am Dent Assoc, Buffalo, v. 125, p. 1330-5, 1994.

TARBET, W. J.; SILVERMAN, G.; STOLMAN, J. M.; FRATARCANGELO, P. A. Clinical evaluation of a new treatment for dentinal hypersensitivity. J Periodontol, USA, v. 51, n. 9, p. 535-540, 1980.

THEOBALD, A. H.; WONG, B. K.; QUICK, A. N.; THOMSON, W. M. The impact of the popular media on cosmetic dentistry. New Zealand Dental Journal, New Zealand, v. 102, p. 58-63, 2006. 